\title{
E-Consumer Protection in a Contract for the Sale of Goods: A Malaysian Perspective
}

\author{
Naemah Amin \\ International Islamic University Malaysia
}

\author{
Roshazlizawati Mohd Nor \\ University of Technology Malaysia
}

\begin{abstract}
The rapid growth in e-commerce witnesses the emergence of a new group of consumers known as econsumers. This new group of consumers is increasing in number over the years as on-line shopping become a trend and a manifestation of the modern life style. However a distance and complex nature of online shopping has led to some new problems and challenges pertaining to consumer protection. One of the perennial problems that needs considerable attention is the adequacy of the existing legislation in Malaysia to meet the basic needs of online consumers. Even though the Consumer Protection Act 1999 (CPA) was amended in 2007 in order to protect the interests of e-consumers, the question remains as to how far the CPA and other existing legislation, namely the Contracts Act 1950, Sale of Goods Act 1957, Direct Sales and AntiPyramid Scheme Act 1993 and Electronics Commerce Act 2006 can protect e-consumers in sale of goods contracts. Therefore, this paper is tasked to generally analyze the existing Malaysian law on sale of goods and to determine the extent to which those laws are adequate in providing protection and preserving the interests of e-consumers in order to overcome their anxieties as well as building up their confidence in purchasing goods online.
\end{abstract}

\section{Introduction}

Sale of goods and services are increasingly being transacted over the Internet which is a borderless virtual market and the world's biggest shopping mall. According to International Data Corporation (IDC) Malaysia, the sales revenue generated by ecommerce in Malaysia register positive year-to-year growth, with $\$ 105$ billion and \$144 billion for 2010 and 2011, respectively [1]. The growth in ecommerce is due to the rapid rise in the number of PCs as well as the growth of WiFi services, broadband and hotspots in Malaysia. This development witnesses the emergence of a new group of consumers known as e-consumers. Econsumers generally refer to the purchaser of goods and services over electronic systems such as Internet and other computer networks. This new group of consumers is increasing in number over the years as on-line shopping become a trend and manifestation of modern life style. A survey done by PayPal for the year 2010 on 400 customers who used it services to pay online indicates that Malaysian has spent RM1.8 billion to purchase goods and services online [2].

On the other hand, unlike traditional method, online shopping does not involve face-to-face communication, and in most cases contracts of sale are not made on paper. It is a distance transaction which provides no opportunity for consumers to examine the good and to know the suppliers and their business places. This paperless and distance transaction potentially raises more complex consumer issues in a sale of goods which not only challenge the way the law deals with them but there are also new issues which have to be addressed effectively. Adopting the method of content analysis, this paper aims to examine the existing Malaysian law on sale of goods and to determine the extent to which those laws are adequate in providing protection to the e-consumers while transacting online. It first provides an overview of e-commerce in Malaysia and follows by a discussion on the general concept of consumer protection in a sale of goods contract. The rest of the paper devotes to the discussion on legal protection for e-consumers under the existing Malaysian law especially the protection afforded by the Consumer Protection Act 1999 (the CPA) and the Direct Sales and Anti-Pyramid Schemes Act 1993.

\section{An overview of e-commerce in Malaysia}

In its broadest sense, e-commerce refers to all commercial activity conducted with the aid of electronic devices [3]. The Organisation for Economic Co-operation and Development (OECD) defines e-commerce as 'all forms of transactions relating to commercial activities involving both organizations and individuals that are based upon processing and transmission of digitized data including text, sound and visual images. It also refers to the effects that the electronic exchange of commercial information may have on the institutions and processes that support and govern commercial 
activities'. Nowadays, e-commerce commonly relates to the subset of transactions conducted via the Internet between parties connected to each other [4]. Thus, any commercial transactions between the parties which are done electronically may be categorized as e-commerce and online shopping is perhaps one of the most important components of ecommerce.

E-commerce has been developed with the considerations of some noble objectives. The benefits of e-commerce are myriad and it depends on each participant's purpose. In fact, e-commerce brings many benefits to both traders and consumers. For traders, online transaction brings greater efficiency, increased responsiveness and reduces cost. It enables small companies and newcomers on the market to extend their reach far beyond what was previously possible. Consumers also stand to gain from wider choice, increased availability of specialized products, more comprehensive product information, lower costs and more responsive services [5]. All in all, this medium of transaction has made the world a smaller place and has enabled business to be carried out 24 hours a day in a seemingly borderless environment.

Nevertheless, online shopping in Malaysia is not as popular as in Western countries but it is fast catching up. According to a study carried out by IDC's Skypad 2008, Malaysia is found to be having the highest percentage $(82 \%)$ of online shoppers among the nine countries surveyed in the Asia Pacific who uses the Internet to purchase travelrelated products or services [6]. The latest study shows that almost $50 \%$ of internet users in Malaysia were e-consumers in 2010 and the percentage is estimated to increase to $55 \%$ in 2012 [1]. This is clearly tremendous development compared to a report by the Malaysian Communications and Multimedia Commission (MCMC) in the year 2005 concerning a survey of the household use of Internet which indicated that only 9.3 per cent of Internet users purchased products or services through the Internet. In addition, according to the IDC, among the items bought by e-consumers, travel-related products top the list at $82.2 \%$ and followed by books $(69 \%)$ and general consumer goods (59\%). With the availability of access to Internet-connected computers as well as mobile phones and tablet computers, be it either at home or office or through facilities such as public libraries, restaurants and cybercafés, nowadays this trend of shopping has become a common mode of transaction.

On the other hand this remarkable development has led to some new problems and challenges pertaining to consumer's legal protection. The main e-consumers concern in Malaysia includes security of payment, data protection, the validity and enforceability of e-contract, insufficient information disclosure, product quality and enforcement of rights
[7][8]. The manner in which online shopping is conducted is different from the traditional transaction whereby it has become more sophisticated, thus exposing and increasing consumer vulnerability to unfair trade practices. A consumer may face various problems, for example in placing an order; the wrong goods delivered or no delivery at all in spite of the fact that payment was made to the supplier through the consumer's credit or debit card. In addition, the consumer may also involve in the problem where the ordered goods are delivered, but when the consumer changes his mind and exercises his right of withdrawal, the supplier refuses to provide a refund. Furthermore, another issue which relates to econsumers in a sale of goods contract is when the right goods are delivered but, after the cooling-off period has elapsed, the consumer finds that the goods are defective in some way.

The above scenarios faced by consumers when purchasing goods online are in fact in line with a report in 2007 by the European Consumer Centre Network (ECC-Net). The network handled over 42,000 requests for information, complaints and disputes across the whole European Union, and less than 10 per cent $(3,780)$ of these cases concerned cross-border online shopping (Factsheet of ECC-Net, 2007). The non-delivery of ordered products was the greatest area of complaint followed by problems with delivery, defective products or non-conformity with the order and lastly problems with contract terms especially those related to the cooling-off period conferred by the Distance Selling Directive on the protection of consumers in respect of distance contracts [Dir 97/7/EC (1997) OJ L144/19]. It is reasonably clear that in the consumer context, most complaints arising from online shopping relate to allegations of non-performance or defective performance by the supplier. The e-consumer's problems are also likely caused by insufficient information disclosure due to unregulated internet contents. These concerns and problems need to be eliminated or minimized to build trust and confidence among the e-consumers.

\section{Regulatory framework for online shopping in Malaysia}

The proliferation of e-commerce needs support from the law in order to build trust and confidence among the consumers. As the aims of consumer protection law and policy are ostensibly for providing consumers with protection from, and rights against, producers and suppliers of faulty or defective goods and services, therefore the law must be developed to suit this new business environment and challenges. In essence, e-commerce is like any existing commercial activity. The major differences lie in the fact that existing legal theories may no 
longer be adequate to deal with the problem that emerged with the development of e-commerce. New forms of abuse and threats to consumer protection call for new protective rules [9]. The protection should be adapted to meet the needs of technological evolution and its implication on the consumers. It is indeed crucial to build consumers' trust and confidence in the information highways through legislative intervention and without doubt that adequate protection of e-consumer rights will have a positive impact on the development of e-commerce itself. Thus, a regulatory framework to ensure econsumers protection is essential and necessary.

In Malaysia, there are different legislations under the jurisdiction of different ministries which directly or indirectly regulate or have an impact on the conduct of online shopping. The primary legislation governing e-commerce transactions is the Electronic Commerce Act 2006 (ECA) under the jurisdiction of the Ministry of Domestic Trade, Cooperatives and Consumerism. The ECA basically provides for legal recognition of electronic messages in commercial transactions, the use of the electronic messages to fulfill legal requirements and to enable and facilitate commercial transactions through the use of electronic means. However the ECA contains no provisions on how electronic transactions could be done in a safe and secured environment which is crucial for e-consumer protection.

Meanwhile the general law on contracts and a sale of goods contracts can be found in the Contract Act 1950 and the Sale of Goods Act 1957. Nonetheless these pre-independence laws are rather outdated and have not yet been amended to suit modern business transactions. The main statute on consumer protection in Malaysia is the Consumer Protection Act 1999 (CPA). The CPA was initially inapplicable to any trade transactions by electronic means but the law has been amended in 2007. Similarly the Direct Sales and Anti-pyramid Scheme Act 1993 has also been amended in 2010 to include e-commerce in the definition of mail order sales. These acts are closely related to the objectives of the paper pertaining to provisions related to protection for e-consumers involving in sale of goods transactions and will be discussed in later sub-topics in more detail.

In addition Malaysia has also developed a set of laws that regulates activities that take place in the cyberspace generally. These cyber laws include the Computer Crime Act 1997 and Digital Signature Act 1997. The Computer Crimes Act 1997 (CCA) primarily makes unauthorized access to computers, programs, data and other IT information an offence. Other offences categorized under the CCA include unauthorized access to computer material, unauthorized modification to the contents of any computer, unauthorized access with the intention of committing or facilitating further offence and wrongful communication of the means of access.
Those acts are criminalized and punishments are provided for such acts. This law is deemed important due to the increase in computer related transactions especially financial transactions. In the context of online shopping, the CCA to some extent protects econsumers' interest with regard to a security of online payment. Another Act that could protect econsumers in terms of securing payments in online shopping is the Digital Signature Act 1997 (DSA). The Act facilitates the development of e-commerce by providing a means for secure online transactions by using digital signatures [10]. The DSA establishes the legal validity, enforceability and admissibility of digital signatures. It addresses the functions of certification authorities, the general requirements for a licensed certification authority, and the application procedures to become a licensed certification authority.

Another important pieces of legislation under the jurisdiction of the Ministry of Information, Communication and Culture are the Communications and Multimedia Act 1998 (CMM), Communications and Multimedia Commission Act 1998 (CMC) and Personal Data Protection Act 2010. The CMM was enacted to provide a regulatory framework to cater for the convergence of the telecommunications, broadcasting and computing industries. Meanwhile, the CMC was enacted to provide for a Malaysian Communications and Multimedia Commission (MCMC) with powers to supervise and regulate the communications and multimedia activities in Malaysia and to enforce the communications and multimedia laws of Malaysia and other related matters. One of the functions of MCMC is providing protection to consumers in the information, technology communications and multimedia industries generally.

In addition, e-consumers' concern with the issue of privacy and data protection has been to some extent answered by the enactment of the Personal Data Protection Act 2010. The Act aims to regulate the processing of personal data of individuals involved in commercial transaction by data user. It provides protection to the individual personal data from being processed or disclosed without the person's consent. The act also imposes on a data user to take practical steps to protect the personal data from loss, misuse, modification, unauthorised or accidental access or disclosure, alteration or destruction [11]. Any infringement of the individual personal data rights under the Act is an offence. Although these cyber related Acts were not designed to specifically deal with e-consumer protection in sales of goods transactions, they can be considered as importance pieces of the regulatory framework which is vital and essential in promoting the ecommerce in Malaysia and thus very helpful in the growth of e-industry. 


\section{E-consumer protection in a sale of goods contract}

In a literal sense a consumer refers to a person who acquires goods or uses services. Practically everyone is a consumer in one way or another of various goods and services supplied by others including public-sector agencies. However for the purpose of consumer protection law, the term 'consumer' has a narrower meaning and it is defined in the context of commercial or business dealings between the consumer and the supplier of goods or services. Section 3 (1) of the Consumer Protection Act 1999 defines a 'consumer' as "a person who -

(a) acquires or uses goods or services of a kind ordinarily acquired for personal, domestic or household purpose, use or consumption; and

(b) does not acquire or use the goods or services, or hold himself out as acquiring or using the goods or services, primarily for the purpose of -

(i) resupplying them in trade;

(ii) consuming them in the course of a manufacturing process; or

(iii) in the case of goods, repairing or treating, in trade, other goods or fixtures on land."

In other words to be a consumer, a person must acquire or use 'consumer goods', that is a kind of goods ordinarily acquired for personal, domestic, or household use and the goods must not be acquired for commercial purposes stated in (i) (ii) and (iii). Thus in Puncak Niaga (M) Sdn Bhd v NZ Wheels Sdn Bhd [2012] 1 MLJ 27, the Court of Appeal decided that a private company who bought Mercedes Benz motor vehicle to be used as a company's car was a consumer.

Development of the law relating to consumer protection is the manifestation of a growing social concern to protect the weak and those unable to take care of themselves in a modern market economy. An inequality of bargaining power is the main justification for additional protection to this vulnerable group [12]. Obviously consumers are in a weak bargaining position compared to the more powerful supplier of goods and services due to the disparity of knowledge and resources. Besides, consumers also need to be protected from all sorts of unfair trade practices of market operators such as protection against sale of defective, substandard and dangerous products and various fraudulent trading practices such as false advertisement, misleading price indication, false description of goods etc. Consumers are also facing problems of insufficient information and limited choice to exercise a prudent product buying decision. Consumer protection laws are thus designed to ensure fair trade competition by preventing businesses that engage in fraud or other unfair practices from gaining an advantage over consumers. The law particularly focuses on a sale of goods contract; the most common type of contract entered into by consumers in their daily life.

Under the existing Malaysian law, a contract of sale of goods including online sale can be divided into three types, namely;

(a) Commercial sales - a contract of sale of goods between a seller and a commercial buyer for business purposes (B2B).

(b) Consumer sales - a contract of sale of goods between a seller and an individual consumer for personal, domestic or household purposes (B2C).

(c) Private sales - a contract of sale of goods between two private persons $(\mathrm{C} 2 \mathrm{C})$.

The main statute governing a sale of goods in Malaysia is the Sale of Goods Act 1957 (Revised 1989) (SOGA). The SOGA applies to contracts for the sale of all types of goods, including second hand goods and makes no distinction between commercial sales and consumer sales. The SOGA is presumably applicable to e-commerce since there are no express or implied provisions which prohibits for the sale of goods over the net. However, the Act which preserves the common law rule of caveat emptor only provides minimal protection for consumers generally and the e-consumers in particular. The nature of online shopping makes it difficult for econsumers to exercise care in making purchases. They do not have the opportunity of examining the goods and of knowing the trader. They also lack the opportunity to ask questions about goods offered. In this sense e-consumers are more vulnerable compared to traditional buyers.

Nonetheless the main protection for e-consumers can be found in the provisions relating to implied conditions as to merchantable quality and fitness of the goods. Another important implied condition relates to a sale by description provided for in section 15.The section implies that goods delivered shall conform exactly to the description. This section is especially crucial since e-consumers rely on the description provided by the retailer on the website and thus all online sales can be categorized as sales by description. However section 62 of the SOGA allows the implied conditions in a contract of sale of goods to be excluded by express terms. Thus the statement that 'the goods sold in this website are not returnable or exchangeable' will bind e-consumers. This kind of clause may operate extremely harsh against the e-consumers because they cannot claim any rights in cases of unsatisfactory quality or defective goods.

It is pertinent to note that the validity of a contract of sale of goods and the general legal requirement for there to be a valid sale of goods is entirely based on the law of contract. Therefore, another important piece of legislation that is worth referring to regarding online contracts is the Contracts Act 1950. It is a codification of English law and it has its roots 
in the Indian Contracts Act 1872. The Contracts Act 1950 is generally applicable to all contracts and agreements enforceable by law. As the rule in the Contracts Act 1950 applies to all forms of communication and it thus includes communications via electronic means. However this outdated Act has yet to be amended and updated to accommodate modern commercial needs. In its present state the Act is not a reference to solve the issue of validity and enforceability of an e-contract since there is no provision on the legal effect of e-mail communication or the web based contracts. The Act does not even provide an answer as to when and where the e-contract is concluded. Similarly the law also needs to be clear with regard to the status of web advertisement. It has been argued that treating the web advertisements as invitation to treat will be of disadvantage to e-consumers, as the consequence is that the merchant is given the freedom to accept or reject the conclusion of contract even after the consumers had paid for the items [13].

There are other basic contractual issues that need to be tackled by the Contracts Act including issues relating to unfair contracts dealings. The existing doctrine of duress, undue influence, fraud and misrepresentation needs to be reviewed to cater its application to online contracts. Since the Act is a statute of general application, it thus treats all parties to a contract alike. It is not reasonable to expect the Act to contain provisions specially aim to protect consumers. After all the law of contract generally has not been a great champion of the rights of consumers. The basic assumption of equal bargaining power in contract law is practically not applicable in a consumer transaction. The greater bargaining power of most traders has enabled them to impose terms and conditions of contract which are not favourable to the consumers.

In addition to the above basic law on a sale of goods, the recognition of the need for some form of consumer protection witnessed the introduction of the Direct Sales and Anti-Pyramid Scheme Act 1993 (DSASA). The Act deals with two types of sales connected to direct selling business, namely, door-todoor sales and mail order sales. 'Mail order' in the original definition is only confined to a tradition mail by post and the Act therefore had no relevancy to econsumers. However in the amendment of the DSASA in April 2010, the scope of mail order has been extended to include 'any other means of mailing including through electronic means'. A new section 19A provides that "no person shall supply by sale, or advertise for the supply of, through electronic transaction, any goods or services except in accordance with this Act or the regulations." A clear effect of the Amendment is that all e-commerce companies must have direct sales licence and comply with the direct sales law and protection for consumers under the Act are now equally applicable to the e-consumers. The most important aspect of online sale is how the goods or services are advertised by the company. Section 20 specifies the contents of advertisement in mail order sales -

(a) the name and licence number

(b) the address of such person, which shall not be a postal box number

(c) the telephone number

(d) a detailed description of the goods or services

(e) the place and time where a sample of the goods may be inspected

(f) the price of the goods or services

(g) the cost and the manner of delivery

(h) the time when the goods or services could be expected to be delivered or performed.

Under section 21 , it is an offence for a person to furnish false information in advertisement and section 22 requires the sample of the goods to be available for inspection by the public at such place and time as may be specific in the advertisement. Failure to do so is an offence under the Act. These regulations obviously aim to protect the consumers from false advertisements and from dealing with bogus company. Further, the DSASA requires a contract which is above RM300 to be made in writing and shall contain the provision of 'coolingoff' period (10 working days). During this time, the consumer has the right to cancel the contract without any reason by giving the written notice to the vendor. However the DSASA is a penal statute which requires strict enforcement to be effective. Thus even though there has been a very significant amendment to the Act, the adequacy of this statute in giving protection particularly to e-consumers has yet to be proven.

\section{E-consumer protection under the CPA}

The CPA is the first legislation that provides specifically for consumer protection in relation to the supply of goods and services [14]. This is expressly stated in the preamble of the purpose of the Act "to provide for the protection of consumers, the establishment of the National Consumer Advisory Council and the Tribunal for Consumer Claims, and for matters connected therewith". Section 2(2) $\mathrm{g})$ of the CPA initially provided expressly that the Act does not apply "to any trade transactions affected by electronic means unless otherwise prescribed by the Minister". Fortunately, the exclusion has been changed through the amendment of the CPA in year 2007 to include "any trade transactions conducted through electronic means" in order to protect the rights of the e-consumers. Therefore, it is understood that the CPA is the law governing the supply of goods and services either offline or online. It means that protection under the CPA applies to all 
consumers regardless of the nature or method of their transactions. The CPA has made a major change in legal concept by setting aside the privity rule, where a mere user of goods can have a claim under the guarantees and a manufacturer can be made liable. All protections provided by the CPA cannot be contracted out and this to some extents solves the problem of exemption clauses in consumer contracts.

The CPA provides for the protection of econsumers against misleading and deceptive conduct, false representations and unfair practices. This is contained in Part 11 of the CPA which mainly concerns with providing sufficient and correct information to the consumer since many of consumers' problem are actually caused by lack of information and awareness of products and suppliers. This is particularly crucial for e-consumers who rely totally on the information given on the webpage. Unfair trade practices in online shopping may include misleading price indication and deceptive advertising technique such as 'bait and switch'. It involves the advertisement of product or services by traders at an extraordinary low price to allure consumers to offer to buy the product. Consumers will then be informed that the product offered was out of stock or not available for various reasons but they have other products (higher-priced one) to be offered [15]. Obviously their real intention is to sale the higher-priced product and the low price offer is just a 'bait'. Section 13 of the CPA protects econsumers from this kind of deceptive advertising technique. Another technique frequently used by etraders is giving gifts, prizes or free offers. Section 14 lays down the rules to be complied with if this method of sale promotion is used. Non-compliance with the regulations under Part 11 is an offence.

Another important aspect of the protection under the CPA includes guarantees as to the quality of goods and services. In this respect the CPA has significantly improved the law on supply of goods by introducing a new concept of implied guarantees especially a guarantee as to acceptable quality (section 32) and a guarantees as to the availability of spare part and repair facilities (section 37). The concept of 'acceptable quality' is undoubtedly more favourable to consumers compared to the concept of 'merchantable quality' under the SOGA. It covers all aspects of goods, not only their quality and suitability but also their safety. The CPA allows the claims for breach of implied guarantees to be enforced against both the supplier and manufacturer. The claim can also be made by a third party or mere user of the goods since the CPA uses the term a 'consumer' who is not necessarily a buyer. However non-contracting consumers may be faced with practical difficulties in enforcing their rights. For example, they may not be able to produce any proof of e-transaction which the e-trader requires before entertaining any claims.
The CPA provides an entirely different remedial scheme for breach of the guarantees which depends on whether the failure in the good is remedial or substantial. In a case of a failure that can be remedied, the supplier may remedy the failure by repairing or replacing the goods or providing a refund where repair or replacement cannot reasonably be carried out (section 42). However, the choice of remedy is not left to the consumer since it needs to be exercised sequentially. The right to reject the good and claim for refund or replacement is only available in cases of substantial failure. The 'substantial defect' has been interpreted by the court to include a defect that either exist as a latent defect at the time of purchase or it might result because of an accumulation of more minor defects which appear one after another continuously over a period of time [16]. In a later case the consumer is only entitled to reject the good at the point where he could be said to have lost confidence in its usability or reliability. It may be seen as favourable and practical remedy for consumers who opt for face-to-face transactions but it might not be the case for e-consumers.

In cases of unsafe product which caused injury or loss to consumers due to a defect in the product, the victims are protected by the scheme of strict liability similar to the protection available in developed countries such as the USA, European Union and Japan [17]. Part X of the CPA imposes the primary liability of losses caused by defective products on the 'producer' (manufacturer, importer and ownbrander). Unlike liability in negligence which is based on the conduct of the producer, the main focus of the strict liability rule is the defect in the product. The liability may be imposed by reason of the existence of a defect alone. However to succeed in a product liability claim, the plaintiff has to prove that the product was defective and his injury was caused by the defect. Sometimes this may not be easy for consumers especially in cases which involve complicated or sophisticated products such as drugs.

In the CPA (Amendment) Act 2010, a new Part $111 \mathrm{~A}$ which deals with unfair contract terms has been inserted into the Act. It is particularly aimed to protect consumers against unfair terms in a standard form contract commonly used by traders and form the basis of most contracts in consumer transactions including online sale of goods. E-consumers may now challenge the validity of standard terms of online contracts for being either procedurally or substantively unfair or both. A procedural unfairness looks at the process of making a contract, whereas substantive unfairness concerns the out-come of the process, i.e. the content or substance of the contract. The new law on unfair contract certainly enhances the rights of the consumer and if it is strictly implemented, it can be considered to some extent as putting an end to unfair terms in consumer contracts in Malaysia. 


\section{Redress mechanism for e-consumers}

E-consumers who are dissatisfied with online dealings can file their claims in the Tribunal for Consumer Claims (TCC) which was set up to provide speedy, inexpensive and informal redress of consumers' grievances [18]. It was established under Part XII of the CPA. The TCC came into being on 15 November 1999, the same date the CPA was enforced. The primary function of the TCC is to hear and determine claims filed by consumers. This includes a claim relating to supply of goods, supply of services and unfair trade practices such as misleading advertisements, misleading price indications etc., provided that the claim does not exceed RM25,000. In addition the TCC may also entertain a consumer complaint under other statutes within the purview of the Ministry of Domestic Trade, Cooperatives and Consumerism such as a hire-purchase transactions, direct selling and pyramid schemes. The jurisdiction of the Tribunal has recently been extended to any "claims in respect of all goods and services for which no redress mechanism is provided for under any other law" (section 98). In other words the TCC may also hear and determine consumer claims in other matters outside the CPA as long as it is not expressly excluded from its jurisdiction.

An e-consumer may lodge his claim by completing a specific form which can be obtained free from the Tribunals. An online trader who disputes the claim must file his defence together with counter-claim (if any) within 14 days after the service of the statement of claim. The Tribunals will then issue a notice of hearing to both parties not less than 14 days before the date of hearing. However before a proper trial is conducted, the Tribunals would assess whether it is appropriate for the parties to negotiate an agreed settlement in relation to the claim. An agreed settlement by the parties shall be approved, recorded and regarded as an award of the Tribunal. Alternatively, the TCC will proceed to determine the dispute if it appears that it would not be appropriate for the Tribunal to assist the parties to a negotiation or when such negotiation process failed. A proper hearing is then conducted but the parties are not allowed to be represented by an advocate and solicitor. However a corporation or an unincorporated body may be represented by its full time employee who may well be a lawyer. At the hearing the parties are entitled to adduce evidence, call any witness or produce any document and other relevant information in support of their case. It is thus very important for the e-consumer to keep records of the communication and transaction with the e-trader.

The TCC is required under the law to make the decisions or awards without delay and, where practicable, within sixty days from the first day the hearing commences. To serve this purpose the TCC will normally proceed to hear and determine the claim notwithstanding the absence of any party to the proceedings as long as a notice of the hearing has been duly served on the absent party. In addition to requiring the respondent to pay damages to the claimant, the TCC may order the respondent to supply or resupply the goods, or to repair or replace the goods, or to refund the price or other consideration paid by consumers. The respondent may also be asked to comply with express or implied guarantees with regard to a supply of goods or services under the CPA. The Tribunal however is not empowered to award any damages for any nonpecuniary loss or damage. The decisions of the TCC are final and shall be deemed to be an order of a Magistrate's Court. A party against whom any order has been made by the TCC must comply with the order within a period of 14 days after the decision is made. Failure to comply with such order amounts to an offence and the defaulting party may be subjected to a criminal penalty. Notably however, the TCC has no extra-territorial jurisdiction and thus its power is confined within Malaysia only. E-consumers who buy goods from online traders operating outside Malaysia may have difficulty in enforcing their rights.

\section{Conclusion}

An online shopping is still a fairly new phenomenon in Malaysia but it has undergone fast development. While e-commerce law is steadily developing and maturing, there are still a number of areas where there is no special legislation to deal with econsumer protection in a sale of goods contract. Undeniably there a number of related consumer protection legislations which can be applied in the context of e-commerce in Malaysia, the issue remains as to whether the present laws suit and cater for the needs of e-consumers. The outdated legislation such as the Contracts Act 1950 and the Sale of Goods Act 1957 are obviously in need of major revamp to suit modern business practices. To a large extent, e-consumers have the same requirements and needs as traditional consumers. However, in many ways, e-consumers are more vulnerable as they typically cannot examine the product prior to purchasing it and may not know who they are buying from. In light of this, it could be suggested that the need for 'trust' is even greater in e-commerce than in offline trade. Therefore, the law plays a crucial role in creating consumer trust in ecommerce.

There has been major legislative reform and development in the area of e-consumer protection in Malaysia for the past few years. The current law on e-consumer protection is not very far behind the 
protection available in developed countries such as the USA and European Union. Nonetheless there are other aspects of e-consumer protection that yet to be regulated such as internet contents and unsolicited commercial e-mails. Review of existing regulations is obviously needed to provide a baseline for national consumer protection in e-commerce so as to strengthen consumer confidence as well as to ensure adequate protection for the e-consumers.

\section{References}

[1] IDC Malaysia (2011), "Southeast Asia ecommerce sales marketing \& market analysis: December 2011 Update, http://www.idc.com.my (10 February 2012).

[2] Nazrin (2011), "PayPal study breaks down Malaysians online spending habits", PC.COM Magazine, www.liveaatpc.com (10 February 2012).

[3] Quirk. P., Forder. J. (2003), Electronic Commerce and the Law, $2^{\text {nd }}$ ed. Wiley, Australia.

[4] Abu Bakar Munir (1999), Cyber Law: Policies and Challenges, Butterworth, Kuala Lumpur .

[5] Sothi Rachagan (1997), 'Consumer law in Malaysia: The need for change', paper presented in National Seminar on Consumer Law in Malaysia: A Reformation, UKM Bangi.

[6] C.T.N.Ling, G.K.Jing, N.T.Hock and L.Y.San (2012), 'Predictors of business to consumers electronic commerce usage among online consumers in Malaysia', in proceeding of the $2^{\text {nd }}$ International Conference on Business and Economic Research (2 $2^{\text {nd }}$ ICBER 2012).

[7] Paynter,J., Lim,J. (2002), 'Drivers and Impediments for e-commerce in Malaysia', Malaysian Journal of Library and Information Science, vol.6, no.2, pp.1-19.

[8] Naemah Amin (2008), 'Legal Protection for Consumers in Distance Selling Transaction', paper presented in $12^{\text {th }}$ National MACFEA Conference, Residence Hotel, UNITEN.

[9] Lee Sai Long (2001), 'Malaysian Cyber laws: Issues and Recent Development', in Proceeding of the Asia Pacific Management Conference, pp:77-84.

[10] Shireen Ng., Ainin Sulaiman (2001), 'A Comparative Study on E-commerce Security Policies', in Proceeding of the Asia Pacific Management Conference, pp:27-36.

[11] F.C.Leong, Halina (2010), 'Personal Data Protection Act 2010', Legal Herald, JulySeptember 2010.
[12] D.Oughton, J.Lowry (2000), Textbook on Consumer Law, $2^{\text {nd }}$ edition, Oxford University Press, UK.

[13] Naemah Amin, Roshazlizawati Mohd Nor (2011), 'Issues on essential elements of formation of e-contract in Malaysia: Econsumers' perspective', Journal of Applied Sciences Research, 7(13): 2219-2229.

[14] Wu Min Aun (2001), Consumer Protection Act 1999: Supply of Goods and Services, Longman Malaysia.

[15] A.Shuhaiza, Izawati Wook (2010), 'Bait and Switch tactics in advertising under Malaysian law', [2010] 1 MLJ i.

[16] Cooper v Ashley \& Johnson Motors Ltd. [1997] DCR 170; Puncak Niaga (M) Sdn Bhd v NZ Wheels Sdn Bhd [2012] 1 MLJ 27.

[17] See generally, Naemah Amin (2007), Product Liability in Malaysia, Sweet \& Maxwell, Kuala Lumpur.

[18] Naemah Amin, Elistina Abu Bakar (2010), "ADR for Consumers: An Appraisal of the Tribunal for Consumer Claims Malaysia" in Mohammad Naqib \& ashgar, Mediation in Malaysia: The Law and Pracrice, Lexis Nexis, Kuala Lumpur. 